\title{
GENERAL ACADEMIC AND PRACTICAL PROFILES - TWO TOOLS FOR CONSTRUCTING A GRADUATE'S SILHOUETTE IN THE FIELD OF FINE ARTS
}

\author{
KATARZYNA CABAN-PIASKOWSKA, ${ }^{1}$ ANNA MIARKA, ${ }^{2}$ \\ MARCIN MIELCZAREK ${ }^{3}$
}

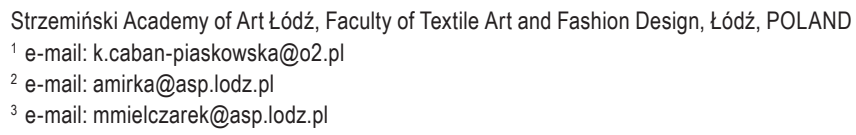

\section{RECEIVED \\ ACCEPTED \\ JEL \\ CLASSIFICATION}

KEYWORDS

ABSTRACT

\author{
4 August 2017 \\ 15 December 2017
}

I23, I25, Z11

general academic profile, practical profile, fine arts, artists

The aim of the article is to present the specific character of the general academic and practical profiles in the field of fine arts that are not natural for the researched profiles i.e.: sculpture (artistic faculty) conducted in the practical profile and industrial design (design faculty) conducted in the general academic profile. The issue of artistic faculties with a practical profile is particularly significant when every faculty created by a newly established organizational unit of a university has to go through studies of the practical profile. The main conclusion resulting from the conducted research is the need to frame detailed and unique regulations on organising studies of the practical profile for artistic faculties.

The data for the research was collected using a participation observation conducted at Strzemiński Academy of Art Łódź between the years of 2009-2017; the result was presented with the use of a case study.

\section{Introduction}

When the idea to divide faculties into profiles - practical and general academic - appeared, it was natural to ask the question how to interpret the idea for each faculty taking into consideration their specific character, the position of each profession, or the kind of competencies offered on the labour market as the result of education. 
Artistic faculties take specific place in the context of division into profiles. It seems that the idea of division is rather addressed to technical or economic faculties. In case of such faculties the number of graduates, their influence on the labour market, the relation between the graduate and the potential employer are in fact areas which require efficient management on the level of the country, the society or even globally. It is no wonder that one of the tools of such management can be the system of higher education constructed in a proper way.

However, in case of faculties where the number of students is rather low, in professions which are essentially very autonomous or èlite such as sculpting, painting, or theatre direction, the division into profiles can raise some doubts - is it reasonable or even possible to be realized? It is said, that in the context of general labour market professions such as a sculptor or an opera singer are so 'exotic' and rare that the factor of studies profile will not affect the possibilities of employment or a graduate's market efficiency in a significant way. Another argument, which stems from common sense and logic, is the fact that artistic jobs are performative as a rule, are deeply practical, even in the general academic profile and as a result, such division is artificial and irrational here.

Is it indeed the case?

\section{General academic and practical profiles - in the context of legal rights}

Regardless of the opinions on the topic, it should be emphasized that legislation (see Act, 2005) offers the possibility to create an artistic faculty with a practical profile (see Act, 2005, article 2, 9a, 11, 168a; Act 2014, article 2, point 18ea). It is also a fact that the requirements for creating new organizational units of universities (faculties) and creating new faculties for the units force the unit to start with studies of the practical profile when creating a faculty.

It is obviously a big challenge - the regulations regarding the way in which the practical studies should be organized evidently concentrate on sectors which are very far from art; the interpretation in the field requires a lot of ingenuity, a kind of intuition and, probably, first of all visionary thinking, a searching attitude, the will to create an educational tool which is supposed to prepare a modern graduate for the labour market (see Bogacz-Wojtanowska, Batko, Hojda, Wrona, Siorek, 2015; Clark, 1998, 2004), who could gain competitive advantage on the market (see Porter, 2001; Obłój, 1998; Kowalak, 2006).

In accordance with the definition of the general academic profile stated in the Higher Education Act, the essence of conducting studies of such profile is to introduce modules of classes connected with research into the curriculum. The legislator does not require job trainings on the faculty with the general academic profile; however, it does not block such a possibility. It is also important for the modules to constitute over $50 \%$ of the ECTS points obtained during the course of studies, thus, the curriculum should be constructed in such a way that it allows conducting research (see Act 2005; Act, 2014, article 2, point 18eb).

Student training known from technical universities indicate that contact with the 'future employer' is sometimes realized in a literal way and close co-operation of a university or a faculty with some specific stakeholder from the market makes (Piotrowska-Piątek, 2014, 2017) the studies take the role of a 'job agency' in a way. However, it should be emphasized that in the most valuable, symbiotic case - the entrepreneur is provided with contact with the precious new blood of experts and has direct guaranteed influence on their competencies (which is guaranteed in the form of studies). On the other hand, the educational unit gains the didactic and sometimes financial possibilities, to conduct studies and a thing which is nowadays priceless - the competitive advantage in the fight for those who 
apply to study (see Obłój, 2002, p. 20), as they can promote the faculty by suggesting that the faculty is potentially a simple way to get employed (see Wytrążek, 2011).

\section{Method}

In order to illustrate the problem presented above, i.e. the characteristic features of the general academic and practical profiles as two tools for constructing the silhouette of a graduate in the field of fine arts the method of a case study was used ${ }^{1}$ (Pieter, 1967). The data used for the case study was collected during a participation observation conducted by the co-authors of the text while creating and organizing different faculties in the discussed profiles, as well as during classes at Strzemiński Academy of Art Łódź between the years 2008-2017: the described cases in the practical (Faculty of Sculpture and Interactive Actions) and the general academic profiles (Faculty of Industrial and Interior Design).

\section{The general academic and practical profiles - a case study}

Qualified employees are precious and more and more rare acquisition. Well-organized teaching can become a stimulating factor for the development of the service market, which can be observed particularly clearly in the sector of design services. Nowadays, it is possible in Poland to teach in one of the two profiles: the general academic or the practical. The decision which profile is used while teaching depends on several factors. One of them is whether the faculty in question offers demand for its graduates on the labour market. It is common practice for external stakeholders - i.e. companies of potential employers - in shaping the teaching program.

\section{The general academic profile - a case study}

The above-mentioned requirements are particularly crucial when organizing the practical profile studies; however, it seems that they should be as natural also for - or even especially for - a design faculty such as e.g. industrial design. The analysed case focuses on the faculty with a general academic profile. Due to the established position of the Department which has been conducting the analysed faculty for over thirty years - it was assigned to the general academic profile. As the result, research and development became the crucial element of teaching such practical studies as designing. The authorities of the Department as well as teachers faced the necessity to organize work in a way that allows both students and teachers were involved in the R\&D activity. It was possible because with the support of the University Technology Transfer Centre the Department has been co-operating with companies within the scope of competitions for implementation projects. Slightly modified form of contracts allowed the companies to extend the co-operation with research and development works. The essence of such activities is not always introducing products onto the market. Sometimes, it can be a small modification of the form of a product or even of a fragment of a production line or shortening the production process by simplifying the assembly. In such a form of co-operation the designer can have a lot of space to use his/her skills and his/her observations and research can impact multiple solutions in a company, even though they do not have to focus on the product itself.

1 The case study method is treated as one of research methods. It is a thorough and versatile picture of few cases of a given phenomenon which aims at collecting empirical data. A deepened, detailed and multilateral analysis is supposed to substitute for large number of data which can be the basis for a statistical study. Sometimes, it can replace the statistical or experimental method. 
Using such - holistic - methods can also positively influence the company's competitive advantage on the market by increasing the attractiveness of its goods and services or the comfort of work for employees.

The number of graduates who found permanent jobs or found their place on the labour market in another way is a very important feedback for the Department. Most often, graduates of the design faculty become self-employed as freelancers and offer their services as projects. If a curriculum is well-constructed and well-organized its graduates do not become unemployed or do not have problems on the labour market. Such a situation undoubtedly influences the increase or maintaining the quality of education on the same high level. It turns out that contact with companies and real orders is one the best working factors which shape young designers. Getting to know the reality of co-operation early, students learn to compromise, to show their vision in a clear and precise way in a form of project presentation, to develop their skills in 3D programs or create interesting solutions on the plane in $2 \mathrm{D}$ graphic programs. In such a situation it is definitely more difficult to get disappointed when facing the reality of the market, which can happen after studies which idealize the world and are not open to the expectations of potential employers. Thus, it seems justified to say that practical design studies in the general academic profile does not have to or even should not lead to a situation where they are far from the reality of the market. Implementing companies in the procedures of research and development can offer very good effects and can lead to increasing the value of products and services. It can also impact the quality of education and increase the competencies of students in a positive way. It seems that the future will bring stronger co-operation between education and industry, especially with the new EU programs which help finance research and development works and scientific research in companies. Combining practical experience of companies with innovative approach of students guided by experienced teachers, often also practitioners of designing, can lead to very interesting effects.

\section{Practical profile - case study}

The factor which in a natural way constructs the practicality of a profile on the faculty of sculpture is actually, the above mentioned perfomativity and workshop of the profession. The appeal for large numbers of laboratory classes for the practical profile is obvious; a huge number of subjects on the faculty of sculpture are workshop subjects. The acquired competencies include a large percentage of physical work. Thus, such a reference is natural. However, it should be emphasized that in the current situation it is difficult to say unequivocally how to differentiate the practical profile from the general academic profile in the context of a sculptor's profession.

Let us focus on another sphere i.e. the contact of a student, a future graduate, with the potential labour market. In the construction of general academic studies the contact is provided via training system. In case of the practical profile the training should be extended, not only via the number of hours, but also through the relation between the student and an employer (as far as to a contract of employment during the course of studies) and via a broader spectrum of those who offer trainings in order to shape the student's idea in terms of future professional 'arena'.

How can the above solution be used in case of an artistic faculty, such as sculpture? It seems impossible - we all know there are no 'factories for sculptors' which hire on the basis of work contracts. An exception can be the field of education of various levels i.e. the possibility to get hired in a primary school as an art teacher or in a culture centre...

In this context the training system is not obviously only a way to find potential employers for the future sculptorgraduate in this narrow scope mentioned above. Network of stakeholders should be constructed in such a way that on one had it should give a student some taste of the width and flexibility of the market which can use his/her 
sculpting competencies, and on the other hand it should stimulate him/her to look for his/her own way to describe his/her strong points which make him stand out among other professional sculptors. Stimulation towards searching for one's own solutions and the network of relations with the market is a separate issue.

Generally, the practical profile for sculpting, seen as the participation of external entities in the course of studies as far as the form of dual studies, should create a kind of training area conditions similar to his/her future professional environment - relations with cultural institutions, business entities, the processes inside the environment etc.

It is hard not to notice that current practice at various universities does not take into consideration the fate of an artist after graduation. Using the master-student relation as the necessary and permanent situation often leads to a situation where a graduate is forced to experiment in order to find the methods of functioning on the market on his/her own because the studies present reality as a safe harbour of a workshop.

However, we might risk saying that, especially in the context of reflections concerning the practical profile of studies, the above formation is largely based on stereotypes or even myths which are popular in the general opinion. Nevertheless, the fact that the stereotypes are also presented more or less officially by the representatives of the profession of sculptors, many teachers, theorists in the field and are reflected in the education curriculums is even worse.

Another question, which stems from the requirements for the practical profile studies, is the choice of staff. The idea that on the practical profile at least half of the teachers had professional experience from outside the university is often inherent for a teacher-artist; it is so common that it is even unaware. There are of course exceptions, units so symbiotically connected with the university, that they are unaware of the existence outside it.

Here, the situation is delicate - in this specific sector of art, where the quality of education depends on such nondiscursive components as the alleged genius loci of the university campus, which impact creative attitudes and students' inspiration. The employers' mobility can sometimes be contrary to the educational value of the university, if it is built on the idea of the so-called 'eternal order of tradition'.

\section{Conclusions}

As always, the solution is obviously balance and proportion - it is a manager's task to manage human resources in a way that does not cause any loss - either from tradition or the one built as the answer to the dynamic contemporary times. And here another use for different profiles emerges - to what extent should the graduate's professional fate be the verifying factor of the above mentioned proportion in comparison to the functioning of the university itself or its subordinate unit - as an educational centre? Introducing different profiles suggests indirectly that these goals require separate tools.

Coming back to the issue of practical profile in general in the context of a sculptor's job - the question discussed above i.e. the commercial (in broad sense) existence of a graduate of an artistic university is the aim which can (and should) be a priority when constructing artistic studies with a practical profile. Let us emphasize clearly, the aim is not to degrade the artist' profession, to make him/her a craftsman, an expert without the artistic independence and freedom, the ethos achieved for centuries. The practical profile is a possibility to construct an artist's - a graduate's silhouette in such a way that $s /$ he could function independently in the contemporary world using his/her creative autonomy. It is a chance to give him/her a kind of arms to protect his/her talents, needs and ambitions against the hardships of market existence. 
What is more, the fact that graduates of the faculty of industrial design at Strzemiński Academy are firstly seen as artists, should motivate them and the management of the faculty to work harder on combining artistic activity which can be and often is designing - with the expectations and reality of the labour market. We should assume that it is possible to create a perfect situation in which the vision of an artist (a designer educated in the general academic profile i.e. connected with research and development) can be joined with extremely precise expectations of an employer who has technology and budget for implementing a product.

The described cases in the practical (Faculty of Sculpture and Interactive Actions) and the general academic profiles (Faculty of Textile Art and Fashion Design) are still being corrected and improved in order to increase the quality of education, facilitate graduates' position on the market and increase the comfort of teaching.

\section{References}

Act as of 27.07.2005 Higher Education Law. Journal of Laws of 2005, no. 164, position 1365.

Act as of 11.07.2014 concerning the change in the act of Higher Education Law and some ther acts. Journal of Laws of 2014, position 1198.

Act as of 5.07 .2005 Journal of Laws of 2005 , no. 11964, position 1365, i.e. Journal of Laws of 2016 position 1842, Announcement of the Marshal of Sejm of Poland of the $26^{\text {th }}$ October 2016.

Bogacz-Wojtanowska, E., Batko, R., Hojda, P., Wrona, S., Siorek, B. (2015). Ogólnopolskie Badanie Losów Zawodowych Absolwentów Uczelni Artystycznych. Retrieved from: http://www.artystapostudiach.pl/public/Og\%C3\%B3lnopolskie $\% 20 \mathrm{Badanie} \% 20$ Los\%C3\%B3w\%20Zawodowych\%20Absolwent\%C3\%B3w\%20Uczelni\%20Artystycznych\%20-\%20raport\%20og\%C3\%B3lny. pdf (19.07.2017).

Clark, B.R. (1998). Creating Entrepreneurial Universities: Organizational Pathways of Transformation. New Jork: Pergamon Press.

Clark, B.R. (2004). Sustaining Change in Universities. Continuous in Case Studies and Concepts. New York: Society for Research into Higher Education \& Open University Press.

Kowalak, B. (2006). Konkurencja gospodarka - innowacje, infrastruktura - mechanizmy rozwoju. Warszawa-Radom.

Obłój, K. (1998). Strategia organizacji - W poszukiwaniu trwałej przewagi konkurencyjnej. Warszawa: PWE.

Obłój, K. (2002). Tworzywo skutecznych strategii - Na styku starych i nowych reguł konkurencji. Warszawa: PWE.

Pieter, J. (1967). Ogólna metodologia pracy naukowe. Wrocław: Ossolineum.

Piotrowska-Piątek, A. (2017). External Stakeholders of Higher Education Institutions in Poland: Their Identification and Significance. Education and Society, 1 (35), 43-61.

Piotrowska-Piątek, A. (2014). Relacje szkół wyższych z interesariuszami zewnętrznymi. Konwent jako organizacja pomostowa. Zeszyty Naukowe Politechniki Śląskiej, Seria: Organizacja i Zarządzanie, 76 (1923), 167-178.

Porter, M.E. (2001). Porter o konkurencyjności. Warszawa: PWE.

Wytrążek, W. (2011). Działalność twórcza i artystyczna jako szczególne przypadki działalności gospodarczej. In: H. Gronkiewicz-Waltz, K. Jaroszyński (eds.), Europeizacja publicznego prawa gospodarczego. Warszawa: C.H. Beck.

Cite this anticle aS: Caban-Piaskowska, K., Miarka, A., Mielczarek, M. (2018). General academic and practical profiles - two tools for constructing a graduate's silhouette in the field of fine arts. European Journal of Service Management, 2 (26), 23-28. DOI: 10.18276/ ejsm.2018.26-03. 